\title{
The Economic Impact of Climate Change on the Agricultural System in Fiji
}

\author{
Mohammed Rasheed Igbal ${ }^{1}$ \\ ${ }^{1}$ College of Agriculture, Fisheries and Forestry, Fiji National University, Koronivia Campus, Nausori, Fiji Islands \\ Correspondence: Mohammed Rasheed Igbal, College of Agriculture, Fisheries and Forestry, Fiji National \\ University, Koronivia Campus, Nausori, Fiji Islands. Tel: 679-994-6619. E-mail: igbalresearch@gmail.com
}

Received: November 30, 2021

Accepted: January 4, $2022 \quad$ Online Published: January 15, 2022

doi:10.5539/jas.v14n2p144

URL: https://doi.org/10.5539/jas.v14n2p144

\begin{abstract}
Climate change is one of the most crucial challenges identified in this century for the Pacific Region, such as Fiji, Samoa, Solomon Islands and many more. Citizens of Fiji have gone through peculiarly climatic and weather conditions over the past years like globalization, which had led to many consequences, especially in the agricultural sector which is the main income of many livelihoods not only in Fiji but in other Pacific countries as well. Climatic conditions have been changing adversely from past decades, such as temperature, rise in the sea level, precipitation changes, atmospheric composition changes, flooding, and tropical cyclones. These changes have led to alterations in the environment, thus, affecting crop and livestock production in the agricultural system. For instance, crops that require specific soil and temperature situations are vastly influenced when the temperature level changes suddenly, making the crops vulnerable to adapt to the alterations and therefore, the crops eventually die. Likewise, animal species also get affected by temperature changes, such as heat stress which specifically affects the fertility of male and female livestock. Due to these events, Fiji's economies have also been affected since agriculture plays a vital role in boosting our economy through local market sales and exporting. Thereby, this review illustrates the impacts of climate change and ways to move forward/ solutions, for example, FAO (Food and Agriculture Organization) and Pacific Islands Climate Change Assistance Program (PICCAP) have supported Fiji in bringing adaptation programs for preparing farmers and all other individuals on the upcoming climatic conditions such as adapting tolerant crops that can handle droughts and other adverse weather conditions.
\end{abstract}

Keywords: climate change, agriculture sector, Pacific Region, PICCAP, FAO

\section{Introduction}

Small island countries like Fiji are highly vulnerable to climatic changes and rise in the sea level due to small landmasses, surrounded by the ocean. Similarly, their locations make them prone to natural disasters. However, Fiji Islands in the Pacific region is located where the climatic conditions are affected and influenced by several factors, like paired Hadley cells, regimes of the trade wind and walker circulation, which varies convergency zones such as the zonal westerlies to the South, semi-permanent subtropical high-pressure belts and the El Niño Southern Oscillation as the central mode of variability year to year (Folland et al., 2002; Griffiths et al., 2003).

According to (Revell, 2004), another fact of the major mode of variability is the MJO (Madden-Julian Oscillation) that affects the oceanic system of the Pacific on time scales of 30-70 days. However, Interdecadal Pacific Oscillation (IPO) is still the leading mode of decadal timescale (Salinger et al., 2001). Numerous p0ublications and studies have suggested that global warming could be a major influencer in emphasizing the cu0rrent climatic conditions and the alterations from normal which approaches with ENSO (El Niño Southern Oscillation) events (Hay et al., 20003; Folland et al., 2003). Daily rainfall and temperature across the Pacific Region from 1961 to 2003 were analyzed, showing a vast increase in the annual number of hot days and warm nights, with a significant downscale of cool days and nights, specifically in the years past the onset of El Nino, whereby, there was an experience of fewer rainfall trends than those of extreme temperature (Manton et al., 2001; Griffiths et al., 2003).

Therefore, all countries and many islands including Fiji, that are the United Nations Framework Convention on Climate Change (UNFCCC) signatories, have been bound to provide the National Communications to the UNFCCC of Conference of Parties(COP). The COP4 released the necessity for parties to the Convention to take 
actions in implementing strategies for sea-level and climatic change adaptations. The Pacific Islands Climatic Change Assistance Program (PICCAP) of the South Pacific Regional Environment Program (SPREP) has been supporting Fiji's contribution to fulfilling the demands of the National Communication, through the Global Environmental Facility (GEF) funding. This requirement and work have been extended so that most adaptations and assessments could be done for Fiji to date (Gavin Kenny et al., 1999).

Thus, these changes and strategies were implemented regarding improving the sudden climatic actions, leading to a better and productive Fiji in terms of economic, tourism and most importantly agricultural growth. This report will illustrate the impacts, challenges and solutions for climatic conditions that affect the agricultural system economically.

\section{Discussion}

\subsection{What Are the Impacts and Consequences of Climate Change on the Agriculture Sector?}

The major contribution to Fiji's GDP and economy has been through our agricultural sector; however, it is also susceptible to changes in the climatic conditions regarding its production capability and capacity. The El Nino drought in 1997-1998 showed the worst climatic change for the agricultural system, such as subsistence agriculture in the Western Division and the sugar industry being harshly affected. Due to this loss, the government had to provide external aid and assistance that were required to facilitate recovery procedures in the worst parts of Fiji that were affected by this drought, which included Northern, Western and Outer Islands (Jone Feresi et al., 2000).

According to (FAO, 2007), the agricultural system including croplands, forests and pastures engross about sixty per cent of the earth's surface and these systems are being gradually exposed to risks, such as increased variability of climate, thus, this leads to abnormal air temperature and rainfall changes which increase intensity and frequency of drought and flood events. There was a thorough study carried out by FAO in 2007; 'ASSESSMENT OFTHE IMPACT OF CLIMATE CHANGE ON AGRICULTURE AND FOOD SECURITY: A CASE STUDY IN VANUATU' in which the climatic conditions were predicted for the years 2050 and 2100 , stating an increase in the temperature and sea-level. The tables below show the figures predicted by SCENGEN generator for Vanuatu.

Table 1. Temperature scenario

\begin{tabular}{lll}
\hline SCENARION & YEAR 2050 & YEAR 2100 \\
\hline CISIRO9M2 & & \\
IS92a(mid) & $0.9^{\circ} \mathrm{C}$ & $1.5{ }^{\circ} \mathrm{C}$ \\
IS92e(high) & $1.5^{\circ} \mathrm{C}$ & $3.0^{\circ} \mathrm{C}$ \\
HADCM2 & & \\
IS92a(mid) & $1.4^{\circ} \mathrm{C}$ & $2.4{ }^{\circ} \mathrm{C}$ \\
IS92e(high) & $2.2^{\circ} \mathrm{C}$ & $4.5^{\circ} \mathrm{C}$ \\
\hline
\end{tabular}

Table 2. Sea-level rise scenario

\begin{tabular}{lll}
\hline SCENARION & YEAR 2050 & YEAR 2100 \\
\hline CISIRO9M2 & & \\
IS92a(mid) & $19.8 \mathrm{~cm}$ & $48.9 \mathrm{~cm}$ \\
IS92e(high) & $39.7 \mathrm{~cm}$ & $94.1 \mathrm{~cm}$
\end{tabular}

Source: Food and Agriculture Organization [ASSESSMENT OF THE IMPACT OF CLIMATE CHANGE ON AGRICULTURE AND FOOD SECURITY: A CASE STUDY IN VANUATU, 2007].

The above Tables 1 and 2 were compared with analogue predictions which were based on past trend observations (FAO, 2007). These scenarios were predicted to know the consequences of climate changes on the agriculture in the upcoming years to suppress the impacts of climatic changes on the agricultural system in Vanuatu and other parts of Fiji, giving an uprise to agriculture growth.

Numerous studies were conducted to assess the potential impacts of climate change on agricultural production (FAO, 2008; Rosegrant et al., 2008; Lobell et al., 2011; Thornton \& Cramer, 2012). According to Thornton and Cramer (2012), conducted projections were for the productivity of the crops to slightly up-rise at mid-high 
latitudes as of local mean temperature that increases from $1-3{ }^{\circ} \mathrm{C}$ since the productivity is limited to the temperature at these latitudes. While, the crop productivity will decrease at lower latitudes, such as small local mean temperature increasing by $1-2{ }^{\circ} \mathrm{C}$ because at this point the crops are already near to their maximum tolerance to heat. However, there are still some doubts about such estimates and examinations (Challinor et al., 2007).

Below are some of the raised consequences that happen due to climatic changes mainly on the ecosystem/environment and subsequently on our agricultural sector.

\subsubsection{Effect of Temperature Change}

According to Challinor et al. (2006), a sustainable increase in the temperature can vary the period of the season where the crops will grow. Short events of high temperature can be harmful if they appear during the critical time of development and thus it can affect the growth and later the yield production of the crop. Not only this, but warm temperature can also affect the crop quality as well. High-temperature periods have been proven to decrease the vitamin content in vegetable and fruit crops (McKeown et al., 2006). Due to these effects, the Asian Development Bank (ADB) conducted a study on the upcoming temperature events, which will occur in future. The data below (Figure 1) is the example for the study that was published in 2013 (ADB, 2004).
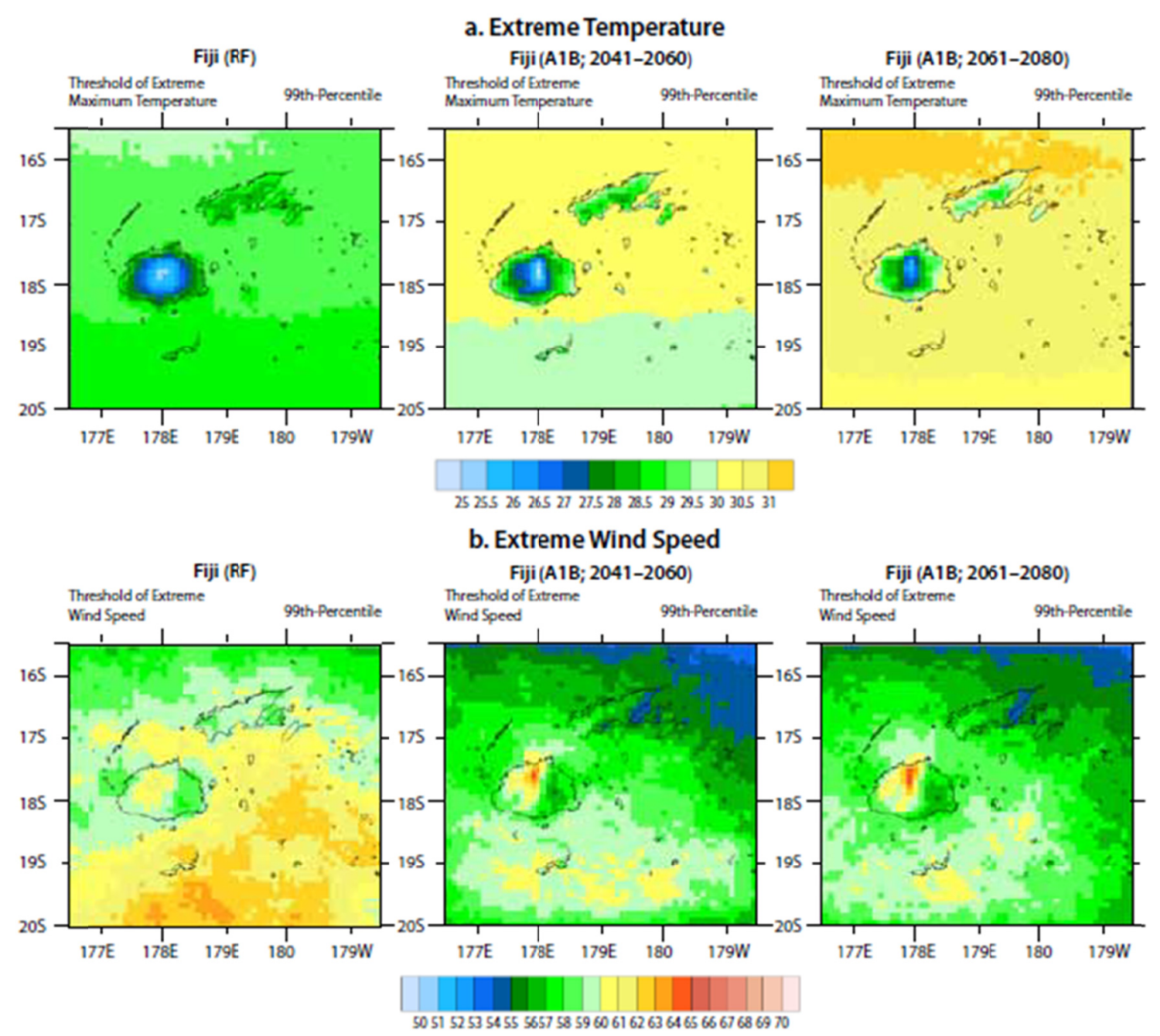


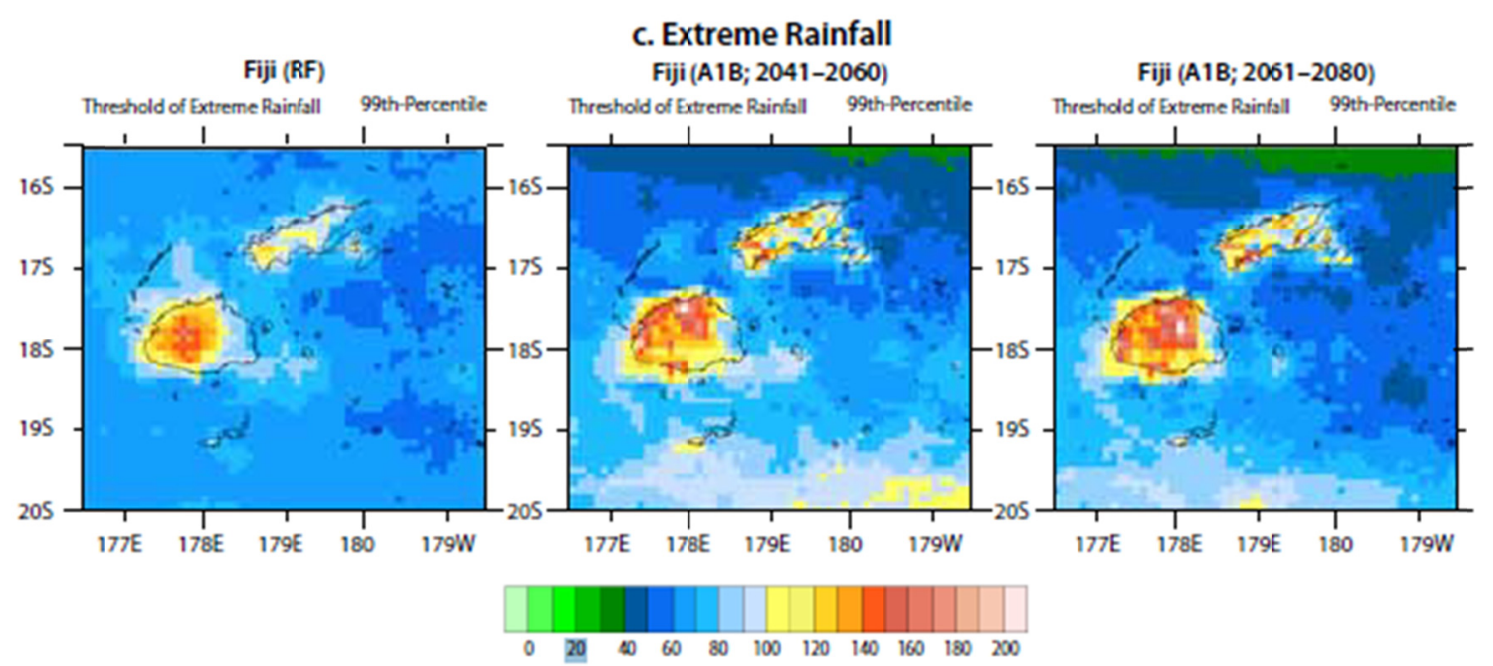

Figure 1. Extreme Temperature, wind speed, and Rainfall in Fiji

Source: ADB Study Team, The Economies of Climate Change in the Pacific, 2013.

In terms of livestock, animals can adapt to a small uprise in temperatures. However, the physiology of livestock, production, male and female fertility can all be affected by heat stress. $42-45^{\circ} \mathrm{C}$ body temperature level is lethal in many livestock species. For instance, poultry, which is highly affected by increased temperatures, specifically when there is high humidity. At a $30^{\circ} \mathrm{C}$ temperature level, the appetite of the animals is suppressed, and they can eventually reduce their feed intake by 3 to 5 per cent for each added degree of temperature. Local breeds grown in tropic and subtropic regions are well adapted to high temperatures, whereas new animals that have been introduced to the tropics are possible to be affected by heat stress (King et al., 2006).

\subsubsection{Effect of Precipitation Change}

Accordingly, the IPCC (Inter-Governmental Panel on Climate Change, 2013) publication suggested that variations in the global water cycle in reaction to warming wouldn't be uniform, thus, an increase in the annual rainfall is projected for bigger parts of the Pacific Regime in a warm climatic condition.

Grable (1966) wrote that an excessive amount of water will lead to soil saturation, waterlogging and oxygen deficiency which can eventually appear over a few days. Thereby, crops will reduce their nutrient uptake and transient waterlogging can decrease the crop yields if they won't be re-fertilized on a time interval basis (Robertson et al., 2009). Changes in the rainfall can also lead to drought conditions which occur to be one of the most common impacts on agriculture, for both animal and crop species leading to heavy loss in the productivity of both species.

\subsubsection{Effect of Atmosphere Composition Changes}

In the past years until recent time, it was predicted that the $\mathrm{eCO}_{2}$ will offset the temperature and rainfalls negative effects. For instance, it was tempted that a 550ppm concentration of $\mathrm{CO}_{2}$ can increase the yield of $\mathrm{C} 3$ plants such as rice and wheat, by almost 40 per cent but field experiments showed that the productivity is less and appear in the range of 8-15 per cent (Long et al., 2005). However, it seemed that tuber crops were more stimulated by e $\mathrm{CO}_{2}$ than the grain crops (Miglietta et al., 1998; Rosenthal et al., 2012).

In the case of the livestock system, alterations in the composition of the atmosphere can affect the productivity of grassland, dynamics, and species composition, which can bring changes to animal diets, and it may reduce the availability of nutrients for animals (Thornton et al., 2009).

\subsubsection{Effect of Tropical Cyclone}

Depending on their intensity, Tropical Cyclones are recorded to be extremely harmful to forestry, livestock, and agriculture, affecting the conditions of crop production, destroying crops and trees, altering water supplies, and drowning livestock. Crops and vegetation are damaged with an increased wind speed of about $180 \mathrm{~km} / \mathrm{hr}$ (A. McGregor \& K. McGregor, 1999). In the past years, Cyclone Ami struck Vanua Levu, which resulted in a great loss for Fiji of about 33 million USD (McKenzie et al., 2005), mainly because of damages done by the flood to the agriculture sector and infrastructure. In 2016, Winston was also one of the most damaging cyclones that 
affected many households and caused a massive decrease in agriculture production. Figure 2 below, clearly shows a vast loss in the agriculture, livestock, and fisheries sector in 2016, whereby, storm surges, flooding and high winds caused by TC Winston led to damages to plantations, forests, and coral reefs (provides habitat to many fish species). This resulted in more production losses and higher production costs to recover from the damages done by TC Winston. Similarly, the production costs continued till 2018 and took a large decline in 2019, except for the fisheries sector as depicted in Figure 2.

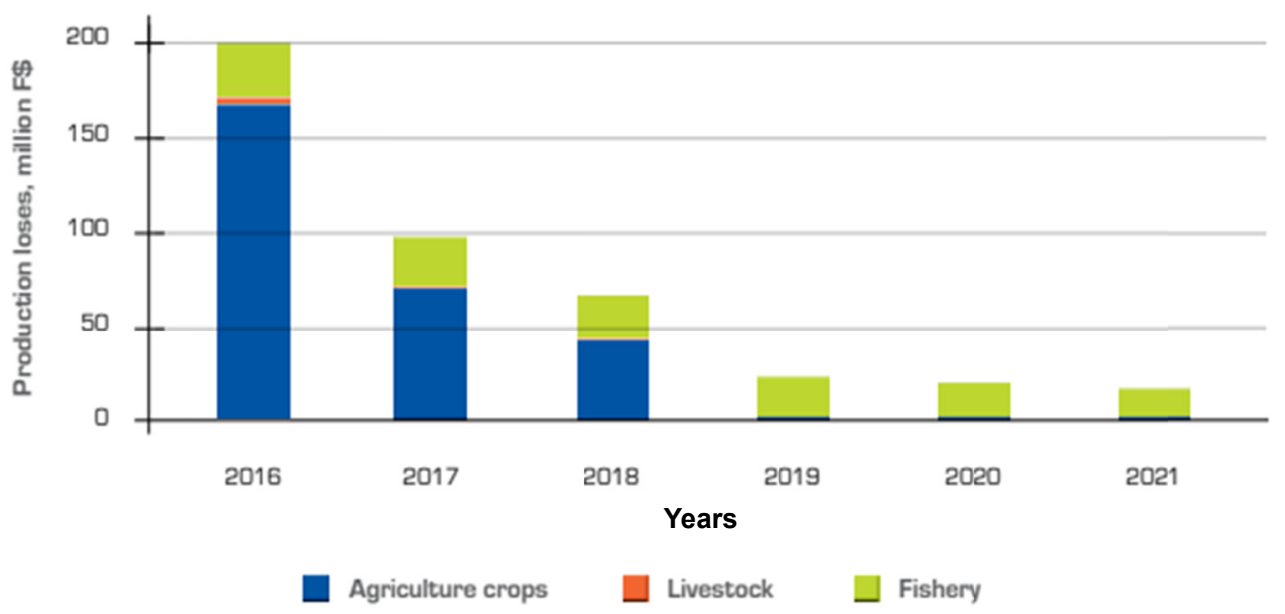

Figure 2. Projected Production Losses in the Agriculture Sector over Time

Source: Estimations by Assessment Team (Fiji: Post Disaster Needs Assessment), Tropical Cyclone Winston, Government of Fiji, 2016.

\subsection{How Does Climate Change Affect Agricultural Economics?}

Climatic changes, like TC Winston, had a large impact on the agriculture sector and its economy. The Forestry sector had \$29.3 million as 5\%, Livestock had \$14.3 million as 3\%, Sugarcane had \$75.3 million as 14\%, Crops had $\$ 216.4$ million as $40 \%$ and fisheries had $\$ 206.5$ million as 38\%. Agriculture products, fisheries, forestry, and livestock were all affected by TC Winston, whereby, their production and profitability were immensely reduced as shown in the pie chart and graph below (Figures 3 and 4), (Simone, 2016). This led to a vast reduction in the income deriving from the agriculture system, thus, their economic growth was decreased as well.

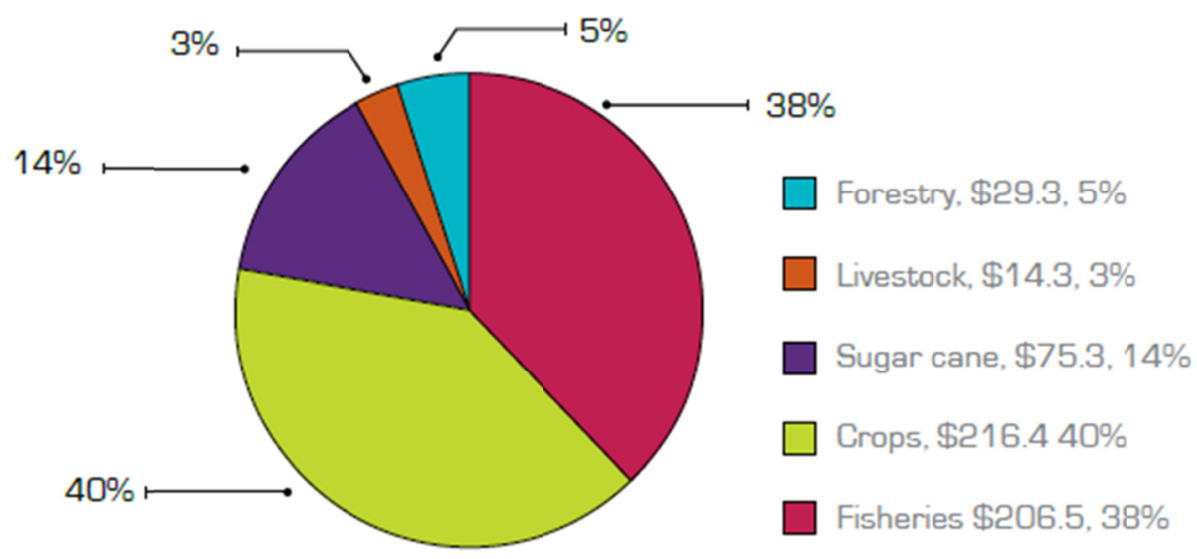

Figure 3. Damage and Losses to Agriculture by Subsector [F\$ million]

Source: Estimations by Assessment Team, (Fiji: Post Disaster Needs Assessment), Tropical Cyclone Winston, Government of Fiji, 2016. 


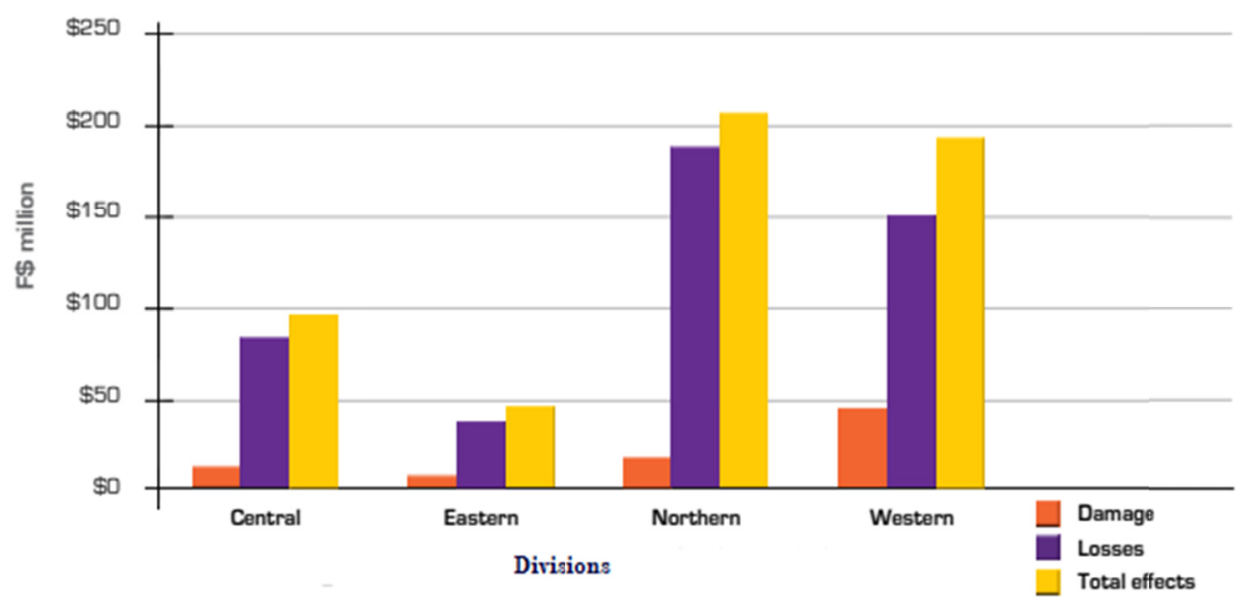

Figure 4. Damage and Losses to the Agriculture Sector by Division [F\$ million]

Source: Estimations by Assessment Team, (Fiji: Post Disaster Needs Assessment), Tropical Cyclone Winston, Government of Fiji, 2016.

Recent publications used projected models to determine the yield and economic cost of climate change in the agricultural sector. CNRM (Centre National de Recherches Météorologiques, the National Center for Meteorological Research [of France]), ECHAM (European Center Hamburg [Germany] Model), and MIROC (Model for Interdisciplinary Research on Climate), models were utilized to forecast the yield of crops in Fiji, (Climate Change, Food Security, and Socioeconomic Livelihood in Pacific Islands, International Food Policy Research Institute, ADB, 2015). In their result, it shows a vast decrease in the yield in most areas of the country due to climatic conditions that will change rapidly in future. The models listed above also illustrated the economic changes in Fiji from 2008-2050. According to their reports, there were losses in cassava and taro production of about \$24 million and \$34 million respectively. However, sugarcane production has been encountered to reduce by $\$ 375$ million approximately. The producers and consumers have been forecasted to bear half the financial cost approximately, due to the impacts of climatic changes that have led to large economic losses in the output of the crops being grown in Fiji. The producers will bear half of these losses due to a decrease in their crops output and consumers will bear the other half due to an increase in the market price for agricultural products (Thomas et al., 2015).

\subsection{How Does Agriculture Impact the Economy?}

According to reports in 2011, done by Food Agriculture Organization, 67\% of the population in the Pacific Region depends on agriculture for their livelihood and income. In previous studies, Fiji's agriculture sector accounts for 15\% of total GDP (Gross Domestic Product), in the year 2000-2009 (World Bank, 2011). In 2010, there was an increase in Fiji's total GDP from the agricultural department, that is, a rise of36 per cent of Fiji's economically active population that was indulged in agriculture (FAO, 2010).

However, the shared percentage of agricultural GDP in Fiji has decreased from 20 per cent in 1995 to 13 per cent in 2009. This was mainly due to increased growth in non-agriculture sectors (Figure 5). 


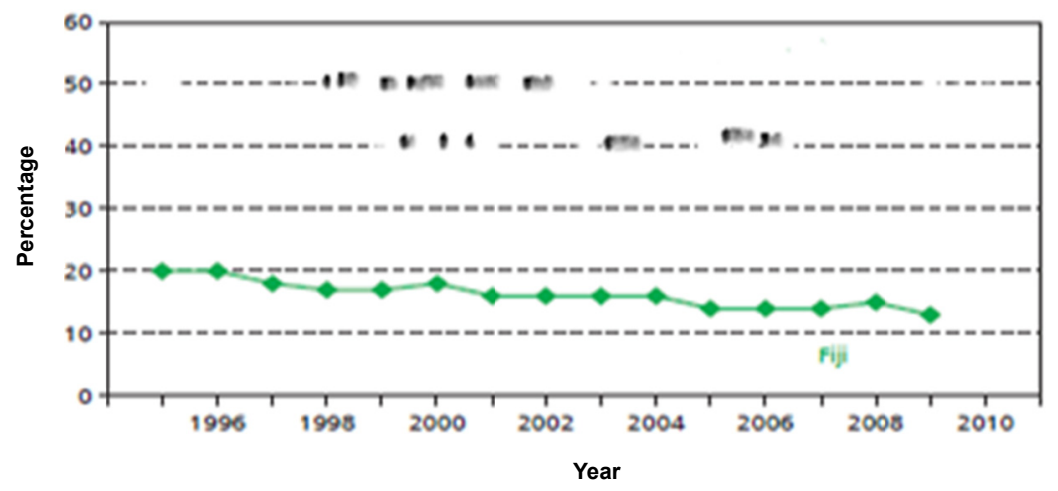

Figure 5. Percentage Share of Agriculture in Gross Domestic Product in Fiji

Note. Based on agriculture GDP as a percentage of real GDP at factor cost.

Source: ADB, 2011, Food Security and Climate Change: Rethinking the Options, Pacific Studies Series, Manila.

The economic performances of enterprises in rural areas were also affected due to a decline in the prices of key commodities and disruption for sugarcane growers. These disruptions contributed to a reduction in the production of sugarcane farming in previous decades (Hone et al., 2008). Moreover, the shared percentage of agriculture to Fiji GDP has also been declined due to natural disasters (climate change), minimum investments in agricultural sectors, deficiencies in the marketplace, and soaring costs in the input. The decline in agricultural private investments was due to a weak business climate.

Therefore, the above facts and figures depict the important impacts of agriculture on Fiji's economy. Though tourism and other industries GDP were more than the agricultural sector, the effect of COVID-19, which commenced in 2019 till present date, led agriculture to be the most contributor to Fiji's GDP and the economy, whereby, individuals who were working in different sectors other than agriculture, the virus impact led everyone to perform farming practices, home gardening and many more. This boosted a vast growth in agricultures economic side.

\subsection{What Will Be the Potential Effect of Climate Change on the Economy?}

Fiji's main Economical Centre and growth depend on the profitability provided by the tourism and agriculture sector. Fiji and other Pacific countries have been experiencing rapid growth of their population and taxing resources which can be further affected by climatic conditions. Because of climate change, our economic growth has been uneven over the past years, the poverty rates are still high and various economies are based narrowly. (Asian Development Bank (ADB), 2004, Pacific Region Environmental Strategy 2005-2009).

A case study was carried out in Viti Levu (Fiji) by the Pacific Islands Climate Change Assistance Program(PICCAP) \& Fiji Country Team in 2005, in which the outcome of the study was based on annualized averages and development of multiple timeframes where the values showed and presented will reflect the year 2050 (midpoint for the coming century). Due to the results being annualized, the estimated values show variability in causes that may arise in gradual events like droughts and cyclones. It's a fact that most of these events will occur in a sporadic fashion way, with greater damages to the economic level than the annualized averages, having important implementations for economic planning and methods in Fiji. For instance, there might be no occurrence of extreme event costs in the national budget in more than 1 year, and then, the government will face a large impact of climate change, specifically a drought of the cyclone which will affect the national budget programs, thus, affecting the economic growth (Feresi et al., 2000). The following Table 3 shows the estimations done for economic damages in Viti Levu. 
Table 3. Summary of estimated economic damages for Viti Levu, climate change-The Fiji Islands Response, 2005

\begin{tabular}{|c|c|c|}
\hline \multicolumn{3}{|c|}{ Summary of Estimated Economic Damages for Viti Levu (c. 2050) (millions of F\$) } \\
\hline Damage Category & Annual Value & Comments \\
\hline Cyclone severity change & -1.3 to 3.9 & $\begin{array}{l}\text { Model projects either decrease or increase in severity; estimates net of economic } \\
\text { development or population growth. }\end{array}$ \\
\hline El Niño-related droughts & 27.5 to 81.3 & $\begin{array}{l}\text { Increased frequency and/or severity, based on events recurring more frequently (or current } \\
\text { frequency but higher severity). }\end{array}$ \\
\hline Loss of mangroves \& related services & 18.0 to 50.2 & Assuming $10 \%$ to $20 \%$ loss; omits several important mangrove services. \\
\hline Loss of coral reef $\&$ related services & 47.3 to 225.7 & Assuming $19 \%$ to $43 \%$ loss; omits several key services, including coastal area protection. \\
\hline $\begin{array}{l}\text { Agricultural output changes due to } \\
\text { temp. or rainfall changes }\end{array}$ & 44.6 to 46.0 & $\begin{array}{l}\text { Dominated by sugar cane losses, but root crops show net decline regardless of } \\
\text { precipitation change (increase or decrease). }\end{array}$ \\
\hline $\begin{array}{l}\text { Public safety } \\
\text { (change in cyclone fatalities) }\end{array}$ & -0.3 to 0.8 & $\begin{array}{l}\text { Cyclone severity is projected to either decrease or increase, based on average } \\
\text { cyclone-related fatalities over past years. }\end{array}$ \\
\hline Increased incidence of dengue fever & 7.0 to 45.6 & $\begin{array}{l}\text { Includes lost productivity, medical costs, and willingness to pay to reduce the risk of a } \\
\text { typical case or a fatal case of dengue fever. }\end{array}$ \\
\hline Increased incidence of diarrhea & 0.6 to 1.4 & $\begin{array}{l}\text { Based on observed incidence in periods of both drought and extreme rainfall events, omits } \\
\text { childhood fatalities. }\end{array}$ \\
\hline Total Damages & 143. & \\
\hline
\end{tabular}

Source: Climate Change-The Fiji Islands Response. Fiji's First National Communication under the Framework Convention on Climate Change, 2005.

On the other hand, economic damage concepts illustrate more of a stock concept. For example, coastal infrastructure damages correspond to harming inventory of the assets and buildings that might be expected to cross the spend value on infrastructure. Adding on, the damage categories show various goods and services that are not being exchanged in the economic marketplace. Thus, the ability of damages exceeding the GDP amount is not necessarily an indication that the estimates are distorted. The comparison demonstrates that the climate change damages can be considered as a considered burden on the people of Fiji and its economy (Neil de Wet et al., 2000).

\subsection{Effects of Climate Change on Selected Crop Production}

According to Barnett and Campbell (2010), crop productivity in the Pacific is estimated to be impacted by global warming negatively. The rate and timing of physiological development can also change due to an increase in the temperature level, which can result in early maturity of the fruits and declined biomass yield and cumulus (Brown \& Rosenberg, 1999; Challinor et al., 2004; Meza et al., 2008). Adding on, tropical cyclones are also a major contribution of climate change effects whereby, they can devastate crops, orchards, vegetation, and livestock. Likewise, cyclones can also cause infrastructure damage like canals, tanks, and wells, hence, causing loss of soil fertility from salinity infringement on a long-term basis (Sivakumar, 2005).

Drought causing low-moisture conditions and dry winds can affect higher yield losses. Similarly, climate change also affects the occurrence, development and spreading of pests and diseases in the environment (Zhao et al., 2005). The coastal lands might also be overwhelmed which can cause agricultural area losses, whereas a rise in the sea level and alterations in the storm patterns can lead to freshwater salinization, which may be needed for crop plantation (Terry \& Chui, 2012). Yet, abiotic stress can also be alleviated by the effect of carbon-dioxide fertilization, which can eventually increase the photosynthesis rate, accumulation of biomass and yield. However, the degree remains unclear to which this effect could be expected (Ainsworth \& Long, 2005). In that way, all the above facts determine how climate change can vastly affect the production of selected crops. For instance, if a crop is selected according to the temperature and area with availability of water resources, changes in the climatic conditions like temperature increase or decrease can highly lead to a vast loss in the production of that selected crop and thus, the profitability will also be reduced.

\subsection{What are the causes of Climate Change?}

Speelman (2009) suggested that either natural processes or human-induced performances can both change climatic conditions in the ecosystem. However, scientific consensus depicts that man-caused actions are more effective and irreversible on climatic changes than natural processes (United States Research Council, 2007).

\subsubsection{Human Causes}

Combustion of fossil fuels emits carbon dioxide which leads to ozone depletion, thus, boosts global warming. Some other factors involve burning of bushes, emissions of smoke from industrial plants, waste (refuse) releasing methane gas, chemical processes, fission and fusion of nucleus, and mining. 
Following are the detailed events that are caused by human actions.

\subsubsection{Greenhouse Gases}

(Mader, 2010) illustrated about the gases that are emitted from vehicles, industries and burning of bushes forms a particle/gas layer in the atmosphere which is eventually invisible. This causes solar radiation to reflect off the earth's surface, thus, boosting the earth's surface temperature.

\subsubsection{Ozone Layer Depletion}

Ozone is classified as a triatomic oxygen molecule that appears at about $20 \mathrm{~km}$ above the surface of the earth. It deflects the UV rays of the sun which protects the earth. Gases like chlorofluorocarbons and carbon dioxide cause one of its molecules to be displaced to reduce the ozone layer into a diatomic molecule. Thus, a hole is formed when the ozone layer depletes and this lets the UV rays pass by and boost the earth's surface temperature, (Mader, 2010).

\subsubsection{Deforestation}

This is one of the most common actions done by men that cause a vast change in climatic conditions. Deforestation is the destruction of vegetation in search of economic benefits. Cutting down trees or plants causes scenarios, whereby the quantity of $\mathrm{CO}_{2}$ emitted to be utilized by vegetation is very high than the vegetation present now, can absorb (Intergovernmental Panel on Climate Change, 2003).

Figure 6 below is being used as an example that depicts carbon dioxide emission and accumulations, illustrating the amount of gas present around humans causing various climatic changes. The data is derived from the Australian Academy of Science [Human activities have increased greenhouse gas concentrations in the atmosphere, 2013].

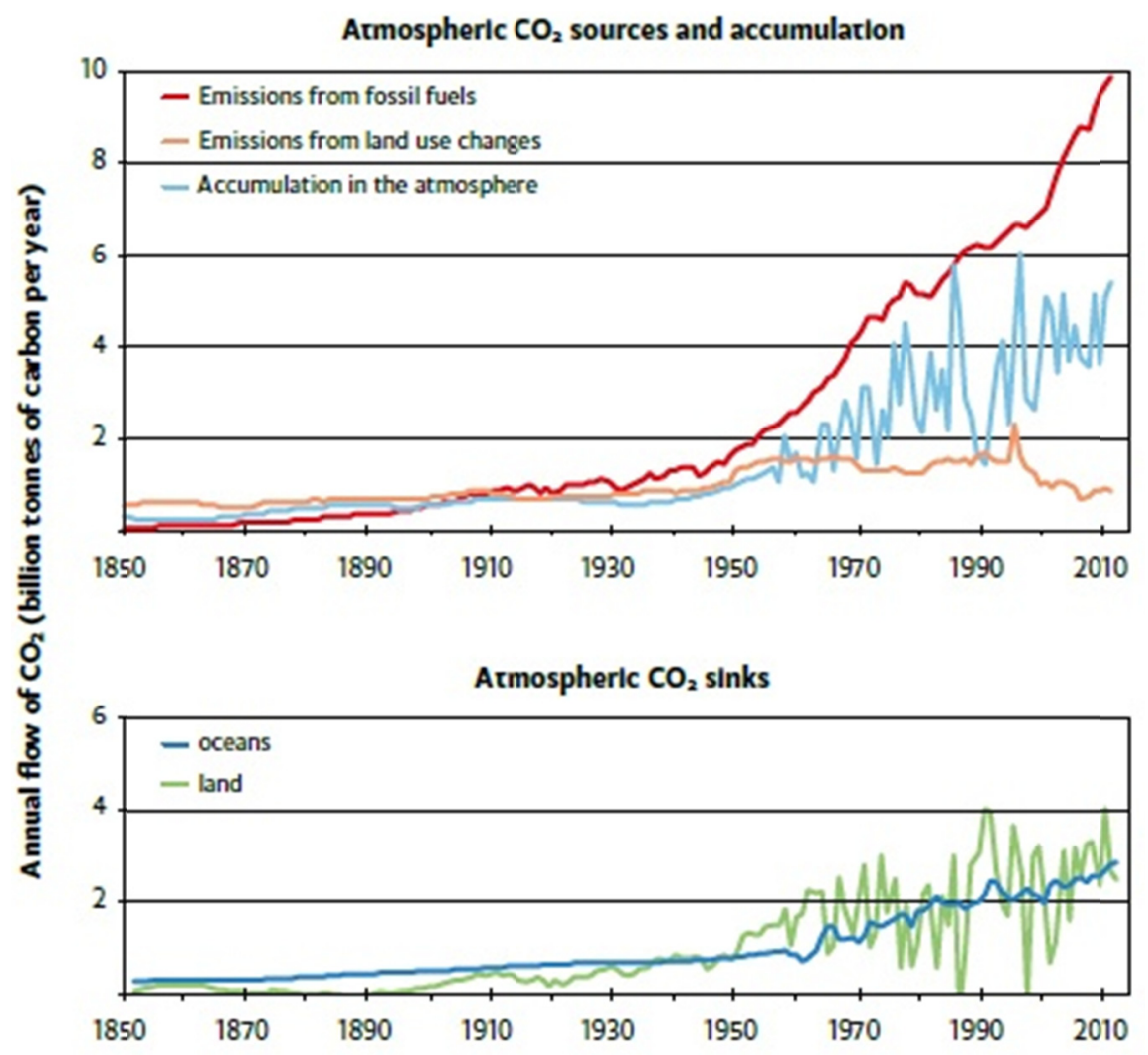

Figure 6. Atmospheric $\mathrm{CO}_{2}$ Budget revealing the amount of carbon entering in the net amounts of $\mathrm{CO}_{2}$, accumulating, and leaving the atmosphere

Source: Australian Academy of Science, Human activities have increased greenhouse gas concentrations in the atmosphere, 2013. 


\subsection{Challenges Faced by Farmers}

The impact of climate change has been felt by many farmers in Fiji, especially those who perform the traditional way of farming. Fiji has also experienced a shift from normal conditions in the weather, which is, seasonal changes, that happen rapidly over time. For instance, during the wet season (Nov-April), the weather becomes hotter and drier and even now, the dry season lasts longer than its normal period which shows the effect of droughts. However, some areas in Fiji experience more rainfall during the dry season, whereby, it causes heavy rainfall to appear in a short period leading to extreme flooding. Thus, these events affect the plantation and productivity of the crops in which farmers experience sudden changes in the weather, and many crops require specific weather conditions (Australian Bureau of Meteorology and CSIRO, 2011).

The local farmers in Fiji have experienced temperature changes in the environment, whereby, the temperature increases and becomes very hot during the daytime while colder during the night. Too much heat restricts their daily activities and thus, farmers have to work very early in the morning and afternoon to prevent themselves from extreme heat and cold. Fiji, during the year 2014, went through a heavy drought condition that affected many farmers/growers. At this point, many of the root crops were affected since the soil was very dry and had less moisture content. Therefore, this led to an increase in the market price of some commodities since producers and suppliers were unable to meet the market demands (Paeniu, 2015). Not only has this, but drought weather conditions also lead to a shortage of water supplies and the farmers significantly had to depend on government assistance.

In terms of flooding issues, many farmers in Fiji had to move to higher ground or inland areas to continue their farming business. These decisions were very difficult for the farmers since finding land to live in and then doing farming is a whole new process for them and most growers in Fiji do not possess that much cash, so they can easily move from one place to another. Therefore, whenever a flood occurs, the most affected people are agricultural farmers.

\subsection{How Does Climate Change Affect Industry?}

Dietz and Stern (2014), Moyer et al. (2014), and Moore et al. (2016) gave justifications that a relationship exists between technology, industrial progress and the climatic changes that are happening around the Pacific region. (Dell, Jones and Olken, 2014), also proved the relationship between economic growth and climate change using econometrics methods.

Acemoglu et al. (2001) states that the impact of institutions clears off the negative effects of climate change on development. Sevilla et al. (2003) used an equilibrium model to find limited effects of climate change on past rates of growth. Statistics derived from International Energy Agency in 2013 shows that there has been an increase in the temperatures and $\mathrm{CO}_{2}$ gases, which can eventually affect the industrial sector.

Flooding and cyclones play a major role in the disruption of industries and the tourism sector as well. These events devastate many industrial buildings and shops as well as hotels, which later leads the businesses to a whole maintenance process to revive from the losses being done (Anthoff et al., 2006). Likewise, the industries and tourism sector also had to go through increased insurance costs. Similarly, food, energy and water resources are all at risk because of environmental and human causes, whereby, the consumer industries report the greatest impact due to these causes.

Not only this but the trading sector is also affected, whereby, climatic changes cause certain alterations in the supply change, like, food supply chains including fishery and agricultural products. Thus, the occurrence of cyclones, high temperatures and floods lead to a vast decrease in these supply chains which furthers leads to losses in the trading sector.

\section{Way Forward}

Climate change adaptive measures are very essential to manage the causes of various climatic conditions and to protect the most vulnerable and poor from an unduly high burden. However, the cost of performing manageable methods is challenging due to the uncertainties of climate change. Nonetheless, estimations done for adaptation costs give useful information to support decision-makers (organizers, stakeholders, government) in the Pacific in scheming their adaptive strategies with guidelines to help and support almost all the communities and individuals, (Stern, 2013, The Pacific Islands Climate Change Assistance Program).

(PICCAP) supported many Pacific governments including Fiji, through a task team comprised of experts from NGO'S, government agencies and private sectors, whereby, they were designed to provide national communication reports to UNFCCC in 1998. The national communication report involves the vulnerability of the Pacific to climate change and a nation's capacity for adaptation to adverse effects of climatic conditions. The 
PICCAP community also provides funding to stimulate vulnerability assessments, that is; GHG (greenhouse gas) emission report; a moderation workshop; building of international negotiations and awareness programs that will involve the government and many other community sectors (Asian Development Bank, 2005).

Countries in the Pacific including Fiji supported By FAO (FAO, 1999) came up with approaches for adaptative measurements in the agricultural sector for developing schemes against climatic changes. This approach suggested by FAO is to emphasize "Research and Extension of Flexible Farming Systems that will be Tolerant to Climatic Stress and Variability" (FAO, 1999). Systems like this should be part of a comprehensive and interspersed approach, which will obtain various and multiple inter-dependencies, that is, between the water and land resources, coastal areas, and the interaction of humans with these resources. However, these strategies must be rational with national terms and policies, especially those strategies which involve environmental management and community participation.

The strategies placed by FAO for Fiji were as follows:

(1) Establishing Commodity Development Framework (CDF) which will aim to boost the economic growth of subsistence communities in Fiji.

(2) Prepare a policy for draft land use in Fiji, which will include suggestions and recommendations aimed at imperishable management of the land resources in Fiji.

(3) Merging of research and extension divisions will help and provide better opportunities for research in the farming system.

(4) CDF program introduced in Land-use Planning Section to derive sustainable practices for land use, specifically in sloping land areas that are prone to erosion.

(5) Establishing a Geographical Information System, within the planning section of the Land-use Program, aiming to provide correct information on crops that would suit which type of soil and climatic conditions.

The strategies mentioned above could be enhanced furtherly by putting a much stronger emphasis on decreasing the effects of extreme climatic changes. The 1997/1998 El Nino drought has created a high awareness of putting these strategies into action (FAO, 1999). Likewise, the communities are encouraged to make decisions and choices that will be for the betterment of their livelihoods. However, this brings multiple challenges, since different commodities possess different perceptions and give various feedbacks regarding the climatic changes that are happening. Not only this, but communities also give information on old risks, for instance, poverty, development, and environmental degradation, thus, increasing the difficulties in providing them with more extension and research services (Heltberg et al., 2012)

There have been many indications suggesting that there are groundwater reserves in the west. However, the benefits of getting water from these reserves should meet the costs of irrigation scheme establishment. Adding on, possibilities of reduced income return from crop productions has become a need that needs to be considered. Better land areas that are suitable for selected crops could help in obtaining higher-value crops like sugarcane and root crops (dalo, cassava). This situation is still being accessed due to uncertainty over land leases, (Campbell, 1985).

Due to a possibility in El Nino Drought striking again in Fiji and damaging not only root crops but other vegetations as well, higher, and better adaptation capabilities have been considered for crops, whereby, land management strategies will be developed to put accurate costs for drought proofed selected crops. Thus, this will help in growing plants that are more tolerant to drought events happening in Fiji, which will eventually lead to a vast increment in the agricultural sector as a whole, (Krishna, 1981).

In this manner, it is a need to implement strategies on extreme climatic conditions that are changing rapidly, so that Fiji's agricultural sector including crops and livestock as well as industrial and tourism sectors could be protected from the upcoming climatic changes.

\section{Conclusion}

This review indicates that climatic changes have been affecting our agricultural sector, industrialism, and the economy. Many Fijians around the country are still struggling with the impacts of climate changes like TC Winston. Since Fiji is still a developing country, it becomes very difficult for the government assistance to provide full support for all the farmers in Fiji because they had to make decisions upon their economic budget. Therefore, several farmers are still facing challenges in their crop productions whereby, they are not able to get enough resources and knowledge on how to adapt to these climatic changes. 
However, with the help of FAO and PICCAP, Fiji was able to adapt to relevant programs that could help the farmers and other individuals in adapting to changes in climatic conditions, for instance, providing and educating farmers through research and extension programs, so that farmers can determine the sudden changes in the weather and can make advance plans on their farming system. This will eventually lead to higher farming production and profitability. Not only this but the programs being adapted could also help in the utilization of scarce land resources available to the farmers, thus, empowering their abilities to overcome the challenges of climate change in the upcoming years. Research and Extension programs have also become lit in terms of educating and empowering growers to adapt to a new style of farming systems which will eventually assist in adapting to climatic changes.

\section{Acknowledgements}

The author extends their profound gratitude to Dr. Jahangeer Akbar Bhat, Dr. Royford Magiri, Ms. Prathna Vikash and Mr. Ubaadah Bin Iqbaal for their outstanding contribution.

\section{References}

Acemoglu, D. (2001). The colonial origins of comparative development: An empirical investigation. American Economic Review, 1369-1401. https://doi.org/10.1257/aer.91.5.1369

Ainsworth, E. A., \& Long, S. P. (2005). What have we learned from 15 years of free - air CO 2 enrichment (FACE)? A meta-analytic review of the responses of photosynthesis, canopy properties and plant production to rising CO 2. New Phytologist, 165 (2), 351-372. https://doi.org/10.1111/j.1469-8137.2004.01224.x

Anonymous. (n.d.). Are Human Activities Causing Climate Change? Retrieved from https://www.science.org.au/ learning/general-audience/science-climate-change/3-are-human-activities-causing-climate-change

Anthoff, D. (2006). Equity weighting and the marginal damage costs of climate change (Rep.). FNU working papers. https://doi.org/10.2139/ssrn.983032

Asian Development Bank. (2004). Pacific Region Environmental Strategy 2005-2009. Key Indicators for Asia and the Pacific 2013: Asia's Economic Transformation-Where to? How and How Fast? Manila (Vol. 1). Asian Development Bank.

Australian Bureau of Meteorology and CSIRO. (2011). Climate Change in the Pacific (Vols. 1 \& 2, Regional Overview and Country Reports, Rep.).

Barnett, J., \& Campbell, J. R. (2010). Climate change and small island states: Power, knowledge and the South Pacific. Abingdon: Earthscan. https://doi.org/10.4324/9781849774895

Brown, R. A., \& Rosenberg, N. J. (1999). Climatic Change, 41(1), 73-107. https://doi.org/10.1023/a:10054 49132633

Challinor, A., Wheeler, T., Craufurd, P., Slingo, J., \& Grimes, D. (2004). Design and optimisation of a large-area process-based model for annual crops. Agricultural and Forest Meteorology, 124(1-2), 99-120. https://doi.org/10.1016/j.agrformet.2004.01.002

Challinor, A., Wheeler, T., Garforth, C., Craufurd, P., \& Kassam, A. (2007). Assessing the vulnerability of food crop systems in Africa to climate change. Climatic Change, 83(3), 381-399. https://doi.org/10.1007/ s10584-007-9249-0

Challinor, A., Wheeler, T., Osborne, T., \& Slingo, J. (2006). Review of assessing the vulnerability of crop productivity to climate change thresholds using an integrated crop-climate model. Avoiding Dangerous Climate Change (pp. 187-194). Cambridge University Press, Cambridge, United Kingdom.

Dietz, S., \& Stern, N. (2014). Endogenous growth, convexity of damages and climate risk: How Nordhaus' framework supports deep cuts in carbon emissions (Working paper). https://doi.org/10.2139/ssrn.2471019

FAO (Food and Agriculture Organization of the United Nations). (1999). Research and Extension of Flexible Farming Systems that will be Tolerant to Climatic Stress and Variability. Rome, Italy: Food and Agriculture Organization of the United Nations.

FAO (Food and Agriculture Organization of the United Nations). (2008). Climate change and food security: A framework document (pp. 1-107). Rome, Italy: Food and Agriculture Organization of the United Nations.

FAO (Food and Agriculture Organization of the United Nations). (2010). FishStatJ statistical database. Rome, Italy: Food and Agriculture Organization. Retrieved from https://www.fao.org/fishery/statistics/software/ fishstat/en 
FAO (Food and Agriculture Organization). (2007). Adaptation to Climate Change in Agriculture, Forestry and Fisheries: Perspective, Framework and Priorities. Rome, Italy: Food and Agriculture Organization of the United Nations. Retrieved from https://www.fao.org.com

Feresi, J., \& Neil, D. (2000). Climate Change Vulnerability and Adaptation Assessment for Fiji (Tech.). International Global Change Institute (IGCI), University of Waikato.

Folland, C. (2002). Relative influences of the Interdecadal Pacific Oscillation and ENSO on the South Pacific Convergence Zone. Geophysical Research Letters, 29(13). https://doi.org/10.1029/2001gl014201

Folland, C., Salinger, M., Jiang, N., \& Rayner, N. (2003). Trends and Variations in South Pacific Island and Ocean Surface Temperatures. Journal of Climate, 16(17), 2859-2874. https://doi.org/10.1175/15200442(2003)016<2859:tavisp>2.0.co;2

Gavin Kenny, K., Warrick, Y., \& Wet, N. (1999). Climate Change Vulnerability for Fiji. Fiji: International Global Change Institute (IGCI).

Government of Fiji. (2007). Pacific Adaptation to Climate Change Fiji Islands Report. Government of Fiji, Fiji. Retrieved from http://fijiclimatechangeportal.gov.fj/document/pacific-adaptation-climate-change-fiji-islan ds-report

Grable, A. R. (1966). Soil Aeration and Plant Growth. Advances in Agronomy, 57-106. https://doi.org/10.1016/ s0065-2113(08)60648-3

Griffiths, G., Salinger, M., \& Leleu, I. (2003). Trends in extreme daily rainfall across the South Pacific and relationship to the South Pacific Convergence Zone. International Journal of Climatology, 23(8), 847-869. https://doi.org/10.1002/joc.923

Hone, P., Hazler, H., \& Natasiwai, T. (2008). Agricultural Supply Response in Fiji. Contributed Paper Presented to 52nd Annual Conference (Tech.). Australian Agricultural and Resource Economics Society, Canberra.

IPCC (Intergovernmental Panel on Climate Change). (2003). An Article on Global Warming in Africa. IPCC.

Jone, F. (2000). Climate Change Vulnerability and Adaptation Assessment for Fiji (p. 3). Fiji: International Global Change Institute (IGCI) University of Waikato.

King, J. M., Parsons, D. J., Turnpenny, J. R., Nyangaga, J., Bakari, P., \& Wathes, C. M. (2006). Modelling energy metabolism of Friesians in Kenya smallholdings shows how heat stress and energy deficit constrain milk yield and cow replacement rate. Animal Science, 82(5), 705-716. https://doi.org/10.1079/asc200689

Lobell, D. B., Schlenker, W., \& Costa-Roberts, J. (2011). Climate Trends and Global Crop Production Since 1980. Science, 333(6042), 616-620. https://doi.org/10.1126/science.1204531

Mader, S., \& Running, S. W. (2010). Drought-Induced Reduction in Global Terrestrial Net Primary Production from 2000 through 2009. Science, 329(5994), 940-943. https://doi.org/10.1126/science.1192666

Manton, M., Della-Marta, P., Haylock, M., Hennessy, K., Nicholls, N., Chambers, L., ... Yee, D. (2001). Trends in extreme daily rainfall and temperature in Southeast Asia and the South Pacific: 1961-1998. International Journal of Climatology, 21(3), 269-284. https://doi.org/10.1002/joc.610

McGregor, A., \& McGregor, K. (1999). Disasters and agriculture in the Pacific Islands. South Pacific Disaster Reduction Programme (RAS/92/360). UN Disaster Management Program-South Pacific Office (UNDMP-SPO), Suva, Fiji.

McKenzie, E., Kaloumaira, A., \& Chand, B. (2005). The economic impacts of natural disasters in the Pacific (Rep.). University of the South Pacific and the South Pacific Applied Geoscience Commission, Suva, Fiji.

Mckeown, A., Warland, J., \&Mcdonald, M. (2006). Long-term climate and weather patterns in relation to crop yield: A minireview. Canadian Journal of Botany, 84(7), 1031-1036. https://doi.org/10.1139/b06-080

Meza, F. J., Silva, D., \& Vigil, H. (2008). Climate change impacts on irrigated maize in Mediterranean climates: Evaluation of double cropping as an emerging adaptation alternative. Agricultural Systems, 98(1), 21-30. https://doi.org/10.1016/j.agsy.2008.03.005

Miglietta, F., Magliulo, V., Bindi, M., Cerio, L., Vaccari, F. P., Loduca, V., \& Peressotti, A. (1998). Free Air CO 2 Enrichment of potato (Solanum tuberosum L.): Development, growth and yield. Global Change Biology, 4(2), 163-172. https://doi.org/10.1046/j.1365-2486.1998.00120.x

Paeniu, L. (2015). Coastal Protection: Best Practices from the Pacific. 
PICCAP. (2005). Pacific Islands Climate Change Assistance Programme (PICCAP \& Fiji Country Team, Department of Environment). Fiji's Initial National Communication, Government of the Fiji Islands.

Revell, M. (2004). Pacific Island weather and the MJO. NIWA. Retrieved from https://niwa.co.nz/climate/ icu/island-climate-update-42-march-2004/feature-article

Robertson, R., Nelson, G., \& Timothy, S. (2009). Climate change: Impact on Agriculture and Costs of Adaptation (Rep.). International Food Policy Research Institute, Washington DC, United States of America.

Rosegrant, M. W., Ewng, M., Yohe, G., Burton, I., Huq, S., \& Valmonte-Santos, R. (2008). Climate Change and Agriculture Threats and Opportunities. Federal Ministry for Economic Cooperation and Development.

Rosenthal, D. M., Slattery, R. A., Miller, R. E., Grennan, A. K., Cavagnaro, T. R., Fauquet, C. M., ... Ort, D. R. (2012). Cassava about-FACE: Greater than expected yield stimulation of cassava (Manihot esculenta) by future $\mathrm{CO}_{2}$ levels. Global Change Biology, 18(8), 2661-2675. https://doi.org/10.1111/j.1365-2486. 2012.02726.x

Simone, E. (2016). Tropical Cyclone Winston, Post-Disaster Needs Assessment (Fiji, ACP-EU Natural Disaster Risk Reduction Program, Government of Fiji). Government of Fiji.

Sivakumar, M. (2005). Natural Disasters and Extreme Events in Agriculture: Impacts and Mitigation. Springer, Verlag Berlin Heidelberg.

Speelman, E. (2009). The eocenicrctic arctic azolla bloom: Environmental conditions, productivity, and carbon drawn down. Geobiology, 155-170. https://doi.org/10.1111/j.1472-4669.2009.00195.x

Terry, J. P., \& Chui, T. F. (2012). Evaluating the fate of freshwater lenses on atoll islands after eustatic sea-level rise and cyclone-driven inundation: A modelling approach. Global and Planetary Change, 88-89, 76-84. https://doi.org/10.1016/j.gloplacha.2012.03.008

Thomas, S., Dawei, Q., Gian-Kasper, P., \& Tignor, M. (2013). Contribution of Working Group I to the Fifth Assessment Report of the Intergovernmental Panel on Climate Change (Rep. No. IPCC, 2013). Cambridge University Press, Cambridge, United Kingdom and New York, United States of America.

Thomas, T., Rosegrant, M., You, L., \& Chiang, C. (2015). Climate Change, Food Security, and Socioeconomic Livelihood in Pacific Islands (Rep.). International Food Policy Research Institute, ADB.

Thornton, P., \& Cramer, L. (2012). Impacts of climate change on the agricultural and aquatic systems and natural resources within the CGIAR's mandate (CCAFS Working Paper 23). Copenhagen, Denmark: CCAFS. Retrieved from https://cgspace.cgiar.org/handle/10568/21226

Thornton, P., Steeg, J. V., Notenbaert, A., \& Herrero, M. (2009). The impacts of climate change on livestock and livestock systems in developing countries: A review of what we know and what we need to know. Agricultural Systems, 101(3), 113-127. https://doi.org/10.1016/j.agsy.2009.05.002

World Bank. (2011). Data on Papua New Guinea. Retrieved from https://data.worldbank.org

Zhao, T. (2005). Increasing Climate Variability and Change: Reducing the Vulnerability of Agriculture and Forestry. Impacts of present and future climate variability on agriculture and forestry in the humid and sub-humid tropics. Springer, The Netherlands. https://doi.org/10.1007/s10584-005-5938-8

\section{Copyrights}

Copyright for this article is retained by the author(s), with first publication rights granted to the journal.

This is an open-access article distributed under the terms and conditions of the Creative Commons Attribution license (http://creativecommons.org/licenses/by/4.0/). 